\title{
Implementation of Value Engineering in Optimizing Project Cost for Sustainable Energy Infrastructure Asset Development
}

\author{
Sarmad Dashti Latif ${ }^{1 *}$, Fathoni Usman ${ }^{2}$, Bilal M. Pirot ${ }^{3}$ \\ ${ }^{1}$ Department of Civil Engineering, College of Engineering, Universiti Tenaga Nasional (UNITEN), Selangor 43000, Malaysia \\ ${ }^{2}$ Institute of Energy Infrastructure, Universiti Tenaga Nasional, Kajang 43000, Malaysia \\ ${ }^{3}$ Civil Engineering Department, College of Engineering, Komar University of Science and Technology, Sulaimany 46001, Iraq \\ Corresponding Author Email: Sarmad.latif@uniten.edu.my
}

https://doi.org/10.18280/ijsdp.150709

Received: 20 July 2020

Accepted: 11 September 2020

\section{Keywords:}

project management, construction cost reduction, sustainable development, explanation building, function analysis

\begin{abstract}
The purpose of this study is to optimize costs by analyzing a case study of the Energy Utility Company (EUC) project in Malaysia and building the main electric distribution station (MEDS) project specifically. In order to achieve this objective, Value Engineering (VE) technique as one of the proven tools was selected, and three alternatives were applied. The first alternative was to reduce the room sizes of the building. The second alternative was to replace the plaster painting with normal painting, and the last one was to replace painting up to 1.5 meters with 1 meter of the high of walls from the floor. Results approved that the implementation of VE has successfully reduced the cost of the project without compromising the quality of the materials. For the first alternative, $17.1 \%$ of the cost was saved. Regarding the second alternative, $69.8 \%$ of the total cost for ceiling painting was saved, and for the third alternative, $41.6 \%$ of the total cost of walls from the floor was saved. The findings of this research may serve as a guide for engineers, scholars, and constructors to reduce the cost of the building project.
\end{abstract}

\section{INTRODUCTION}

\subsection{Background of VE}

Quality, efficiency, longevity, and enhanced performance across the life projects are considered essential deliverables in a construction project, which can be strengthened by integrating 'sustainability' and Value Engineering (VE) concepts [1]. The society is developing in the direction of internationalization. In the construction market, its development must also keep pace with the international speed. Therefore, it is necessary to build a construction project engineering cost management information system that is compatible with the information age. Due to the design and implementation of the information management system, it can not only efficiently increase the quality of the work in the construction project cost cycle but also allow good use of knowledge and efficient management [2-4].

Value Engineering (VE) is an organized procedure to achieve the essential functions at the most minimal life-cycle costs predictable with required performance, reliability, availability, quality, and safety for a specific product. Value Engineering is a function-oriented approach that illustrates the ratio between "what you get" (function) and "what it costs" (source) as a description of the value. Accordingly, Value Engineering acknowledges that all contributing disciplines share the same understanding of functions provided by the item [5-8].

Value Engineering (VE) is a systematic method for advancing goods, products, or services values. It is known as the cost-to-cost performance, production, or lowering costs.
Value Engineering was to be carried out in the new construction industry to ensure that an objective project or cost-optimized project is achieved. The VE has been used for half a century in the building industry in many countries around the world, despite different obstacles in order to deliver high-value projects on schedule and within budget [9-15].

Value engineering is a strong strategy for cost-saving and improving quality; in particular, the construction industry plays a major role in the global economy. Value engineering does not influence the cost reduction only, but also it is improved that value engineering has a positive impact on the development of varieties of constructions. Value engineering takes into account the initial as well as life-cycle costs of the construction projects. Value Engineering approach can be implemented on all the resources around us, such as water, energy, material life-cycle, etc. [16-19].

Value engineering (VE), also known as value management (VM) or value analysis (VA) is a systemic method for enhancing the value of objects of research. The production and management can be optimized by adjusting the function and cost of the research objects and by increasing the ratio of the function of the object to cost. Function and cost are the two crucial factors that define the value of research objects. The value of the object of research can be expressed as Eq. (1):

$$
V=\frac{F}{C}
$$

In the Eq. (1), V, F, and C represent Value, Function, and Cost, respectively. Depending on Eq. (1), In realistic cases, the importance of the research object can be increased from two 
aspects. (1) improving or preserving efficiency and reducing production costs through technical innovation; (2) significantly reducing production costs by eliminating nonvalue or under-value function [20].

In construction Projects, value can be looked at from the proprietor or end client side. Project value has a utility measurement with an intrinsic property to fulfill. It is a deliberate procedure to enhance the value of undertaking through the examination of its capacity at the most reduced life-cycle costs steady with required execution, dependability, accessibility, quality, and security for a specific item $[5,16]$. Even though Value Engineering systems are utilized in construction projects, objectives are not, in every case, simple to distinguish or concur upon. As it is clear from its definition, value is characterized as the proportion of capacity to cost where the value is expanded by either expanding the capacity or diminishing the expense, or by both. Contingent upon this definition and because of the dynamic idea of construction projects and the contention among the project members as well as goals, a fundamental advance in Value Engineering is to set destinations for meeting customers and undertaking necessities. These targets could be to limit capital expenses; expand working period, unwavering quality, and simplicity of support; and accomplish the most elevated conceivable wellbeing gauges [16]. Figure 1 shows the basic approach of Value Engineering.

Some of these objectives struggle with each other. For instance, shorter construction lengths may prompt higher capital expenses, and keeping in mind that higher security and unwavering quality measures raise both capital and working costs, they likewise could increase the customer's throughput and benefit [21]. Struggle additionally happens when a group is framed. A team of experts is formed in an average value engineering workshop from the client and various disciplines, such as architecture, engineering, construction services, and quantity surveying [5]. Figure 2 represents the conflict model of value engineering.
The application of Value Engineering is widely accepted internationally in the United States of America, Japan, Australia, and other developed countries such as European countries. In Malaysia, its application is still in its infancy [22]. Thus, to promote the implementation of VE in the industry, it is pivotal to comprehend the present condition of its application in the industry before a system of Value Engineering can be created to suit the Malaysian construction industry.

This project paper presents a case study of implementing Value Engineering applications in sustainable energy infrastructure asset development. This research aims to show the effect of the Value Engineering approach in the energy infrastructure asset development to optimize and decrease the Malaysian EUC project cost and eliminate the overrun costs. The objectives of this research are to determine the implementation of Value Engineering in the construction project and to evaluate the effects of Value Engineering in optimizing projects' cost for sustainable energy infrastructure asset development. In order to achieve the objectives of this research, the scope of the study is focusing on the collected data from the EUC in Malaysia.

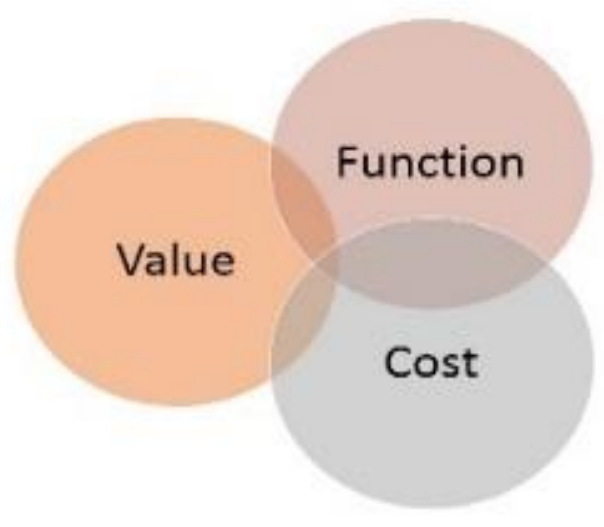

Figure 1. Value engineering approach

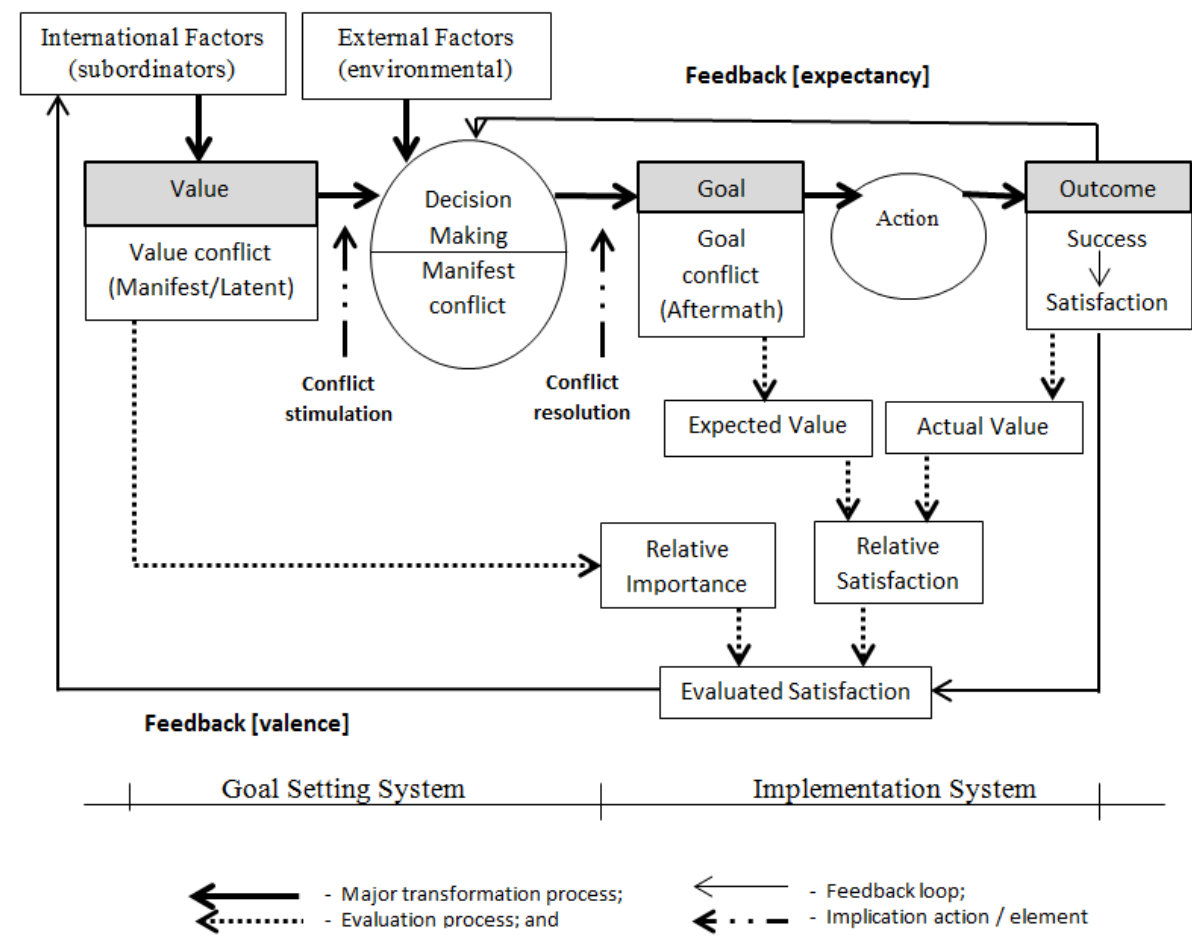

Figure 2. Conflict model of value engineering [21] 


\subsection{VE in construction industry}

Value Engineering was introduced into the construction industry in the early 1960 s by Dell'Isola and became a trend thereafter. It is an orderly and sorted out process that augments the distinctive values of multi-disciplinary partners in a construction project. Customarily, VE is a value upgrading device as opposed to only a technique for cost-cutting [23].

$\mathrm{VE}$ is a concentrated, interdisciplinary critical thinking movement that spotlights on enhancing the value of the functions that are required to achieve the objective, or target of any item, process, administration, or association. Value Engineering is a sorted out methodology coordinated at examining the capacity of frameworks, gear, offices, administrations and supplies to achieve their basic capacities at the least life cycle cost reliable with required execution, quality adequacy and wellbeing. The most astounding execution in VE is accomplished, particularly when the design is primarily expanding the value as opposed to diminishing the expenses. VE is utilized to decide the best outline options for projects [24].

Value Engineering has a considerable measure of preferences going from money related advantages, to building the resolve of the expert group. Value Engineering will influence everybody related to the project, also called partners. The customer looks to accomplish value for money, while the clients need an item that addresses their issues as adequately as would be prudent. The project directors are to guarantee that the undertaking is on time and falls inside the budgetary requirements, the contractual worker wishes to give an administration which will bear the cost of them a satisfactory benefit and the architects are quick to meet the desires of the customer while agreeing to specific norms and execution criteria. Value Engineering can address the vast majority of these necessities straightforwardly or in a roundabout way, along these lines conveying a level of fulfillment to every one of the partners included [25].

Hypothetically, Malaysian specialists have characterized Value Engineering to suit the local Malaysian construction industry situation [26]. Local researchers have endeavored to enhance Value Engineering execution by delivering model rules for Value Engineering usage in the Malaysian construction industry. In addition, guaranteeing manageable Value Engineering usage in the Malaysian construction industry by utilizing the Capacity Building concept [27]. In broadening Value Engineering use, scientists have included the component of sustainable construction projects. Also, Value Engineering is drilled in a way that suits industry needs. For instance, among the present Value Engineering execution forms utilized is the "Hybrid VE" workshop process, which includes a group of facilitators who can deal with in excess of one anticipate at the same time. This methodology satisfies the customers' goal to esteem oversee; however, many projects could be allowed at the underlying stage.

Value Engineering is not a plan/peer survey or a costcutting activity. Value Engineering is an inventive, sorted out exertion, which investigates the necessities of a project to achieve the basic capacities at the most reduced Life Cycle Cost. Through a gathering examination, utilizing experienced, multi-disciplinary groups, value, and economy are enhanced through the investigation of elective plan ideas, materials, and techniques without trading off the utilitarian and esteem goals of the customer. VE can be connected anytime in an undertaking, even in development. Notwithstanding, ordinarily, the prior it is connected, the higher the arrival on the time and exertion contributed [28].

In the relevant industry, VE shall be practiced as early as possible to maximize the result obtained. This is to ensure every alternative suggested or brainstormed will have enough time to be analyzed by the team in charged.

Figure 3 shows that the later the Value Engineering is applied, the lesser the saving potential, two things will increase: the investment required to apply any changes which are recently incurred a higher cost for the project and the resistance to change that can result in a lower quality project. Thus the earlier the Value Engineering is implemented in a project schedule, the higher the value can be produced.

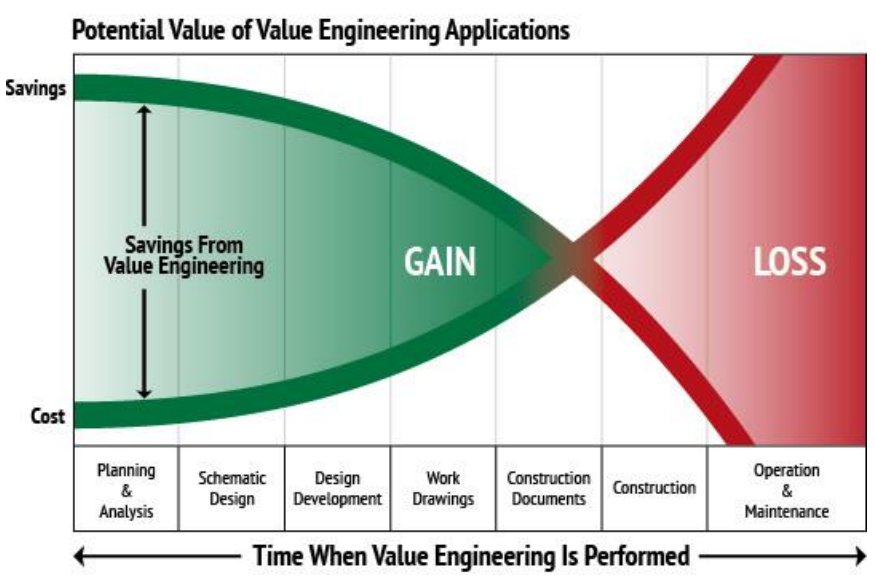

Figure 3. Potential savings from value engineering application

\subsection{VE in optimizing construction projects' cost}

The readiness of project cost estimates is a troublesome errand since construction projects are liable to dangers and vulnerabilities, especially in the beginning periods when exceptionally constrained data about the undertaking is accessible. However, the cost estimates arranged at this stage are most imperative to the undertaking support since they frequently shape the premise of the offer for reserves. Run of the mill investigation of undertaking costs, and also understanding the procedure by which cost estimates are computed and how they may shift amid development, it is beneficial making them comprehend of how vital the diverse cost components are, and how touchy they might be to a scope of cost differing factors. The tables following this page give a general examination of the run of the mill extent of aggregate project costs accounted for by significant cost components. The tables are not total benchmarks but rather are intended to direct work area officers in their general comprehension of the relative centrality of various cost components and cost-shifting variables.

Table 1 provides estimates for seven distinct kinds of framework projects, of the average extent of aggregate task cost that is represented by particular classes of expense. A range is given to indicate how extents may differ from undertaking to extend. The reaches given for the distinctive classes making up introductory costs may empower work area officers to pass judgment on regardless of whether specific project entries should be examined. On the off chance that, for instance, an undertaking demonstrates that land buy costs for a sewage treatment plant add up to at least $10 \%$ of aggregate costs, a work area officer ought to be cautioned to make 
inquiries. This is on account of in average undertakings of this nature, arrive buy costs don't surpass $1 \%$ of aggregate expenses. Once more, if a task support showed that poor ground conditions was the reason that plant and apparatus costs ended up being higher, the work area officer would need to examine the project.

Table 1. Major cost elements and indicative share of total cost for seven infrastructure types

\begin{tabular}{|c|c|c|c|c|c|c|c|}
\hline & $\begin{array}{c}\text { Motorway Dual } \\
(1 \mathrm{~km}) \text { Rural } \\
\text { Area } \\
\end{array}$ & $\begin{array}{c}\text { Motorway Dual } \\
(1 \text { km) Urban } \\
\text { Area } \\
\end{array}$ & $\begin{array}{c}\text { Sewage } \\
\text { Treatment Plant } \\
(50,000 \text { people }) \\
\end{array}$ & $\begin{array}{c}\text { Water Supply } \\
\text { Network (1) } \\
(\mathbf{5 0 , 0 0 0} \text { people) } \\
\end{array}$ & $\begin{array}{c}\text { Public } \\
\text { Building (2) } \\
15,000 \text { m }^{2} \\
\end{array}$ & $\begin{array}{c}\text { Energy I (3) } \\
\text { CCGT Power } \\
\text { Station } \\
\end{array}$ & $\begin{array}{c}\text { Energy } 2 \text { (4) City } \\
\text { Gas Distribution } \\
\text { Network }\end{array}$ \\
\hline $\begin{array}{c}\text { Planning/Design } \\
\text { Fees }\end{array}$ & $3-5 \%$ & $3-4 \%$ & $3-5 \%$ & $5-7.5 \%$ & $10-15 \%$ & $5-10 \%$ & $5-10 \%$ \\
\hline Land Purchase & $3-5 \%$ & $20-30 \%$ & $0-1 \%$ & $1-2 \%$ & $5-15 \%$ & $0-10 \%$ & $0-10 \%$ \\
\hline $\begin{array}{c}\text { Building \& } \\
\text { Construction }\end{array}$ & $75-80 \%$ & $60-65 \%$ & $40-41 \%$ & $75-80 \%$ & $25-38 \%$ & $15-30 \%$ & $20-35 \%$ \\
\hline $\begin{array}{c}\text { Plant \& } \\
\text { Machinery }\end{array}$ & N/A & N/A & $40-41 \%$ & N/A & $10-18 \%$ & $50-60 \%$ & $40-50 \%$ \\
\hline Contingencies & $10 \%$ & $10 \%$ & $10 \%$ & $10 \%$ & $10-15 \%$ & $10-20 \%$ & $10-20 \%$ \\
\hline
\end{tabular}

The study has contributed towards better learning and comprehension of the Value Engineering usage in the Malaysian construction industry towards the improvement of significant worth for the customers and the experts in the industry, by making new elucidations prompting new proof to the collection of information. The real commitment of this exploration is to investigate the idea of Value Engineering and its application in the Malaysian construction industry. Likewise, it additionally also contributes to the clients' operations from a practical standpoint in achieving better value for money for their procured construction projects. An arrangement of Value Engineering application is particularly to be utilized as a source of perspective to any customer needing to create and execute the Value Engineering logic inside their association. The most significant contribution of this research is the advancement of the model Guidelines of Value Engineering Application for the Malaysian Construction Industry.

Probably, Malaysian examiners have portrayed Value Engineering to suit the local Malaysian development industry circumstance [26]. This hypothesis has portrayed Value Engineering as a multi-disciplinary, bunch orchestrated, sorted out, coherent process and exact examination of limit, which searches for the best an incentive by methods for the diagram and improvement process to meet the client's obvious needs. The definition serves to enhance the cognizance and impression of VE framework that clients and experts in the local construction scene generally have. In addition, there are unimportant creations and utilization of Value Engineering data, principles, and manuals in the adjacent development industry, which are impeccable with the general Value Engineering method. Local investigators have endeavored to upgrade Value Engineering execution by making model principles for Value Engineering utilization in the Malaysian construction and likewise ensuring temperate VE execution in the Malaysian construction industry by using the Capacity Building thought [22].

Another study by Rangelova and Traykova [25] showed that Value Engineering is a process whereby the project is evaluated and scrutinized to obtain maximum value for money by following a certain methodology, the process being led by an experienced facilitator. The economy has changed quickly in the course of recent decades and heightening rivalry has put a developing significance and request on expanded proficiency, viability, and value for money. VE addresses these three facets effectively and directly. Value Engineering is a truly beneficial practice that should form an integral part of a project (especially larger and more complex projects) and that it is worth investing some time and effort in the Value Engineering workshop and the process as a whole [29].

Moreover, Benhncke et al. [30] presented an extended model for Integrated Value Engineering (IVE), which combines Target Cost (TC) and Value Engineering (VE) in a far-reaching framework show for build the cost-value-ratio of products. The broadened demonstrate extends the first model for IVE, and its item focused areas prerequisites, capacities, and parts by three spaces get together, assembling and provider that give additional data on the segments of an item. A procedural model is added to permit professionals a simpler and predefined utilization of the broadened demonstrate for IVE. The model supports a systematic procedure for firms to analyze the cost-value-ratio of their products. Results were outlined in a far-reaching model, and possibilities to expand the product value can be examined in and between all spaces. Particularly the traceability of possibilities in the segments space and therewith in the fundamental areas get together, assembling, and provider are featured in their study. A praiseworthy utilize case from the scholarly world delineates the pertinence of the model with comparable outcomes. There are extra highlights of the model for IVE. These highlights cover the utilization of further examination criteria for matrixbased models or the conclusion of circuitous conditions inside the grid to determine additional data of the framework, which surpasses the direct gained data. Besides, extra applications like the correlation and cost streamlining of various item variations are ventures of future research around there. The utilization of the model to more mechanical cases guarantees to uncover the possibilities to enhance the model for IVE.

In another study by Lin and Shen [31], a detailed measurement framework that takes after the procedures of Value Engineering contemplates was created by the starter structure and the recognized key performance indicators (KPIs). The measurement begins from the destinations of the Value Engineering study and is in accordance with the procedures of the examination. The information suppliers for the KPIs are distinguished to keep away from inclination in estimating. A disentangled computation of the weightings of KPIs is presented. With a specific end goal to relieve the subjectivity of scoring, the meaning of each scoring is definitely depicted. The discoveries of the contextual investigation demonstrate that Value Engineering considers which have clearer targets prompt better result execution. The activity inquiries about presents the utilization of the fundamental system to the whole procedure of a Value 
Engineering study. The outcomes demonstrate that a full photo of the execution of the Value Engineering study can be drawn by applying the execution estimation system. A center gathering meeting was directed with the Value Engineering professionals and government agents to test the legitimacy of the structure. The outcomes demonstrate that the customers and Value Engineering facilitators are emphatically arranged toward the structure.

As per Russell Pell et al. [32], absence of capacities to assess openings methodically and accentuation on the capital expense, as opposed to lifetime expenses, would all be able to obstruct capital activities from being completely improved. They have understood that Value Engineering can address this hole and give an unmistakable answer on the best way to harvest generous esteem and upgrade capital ventures. In the interim, organizations are in every case progressively under strain to convey capital ventures on time and under spending plan, expansive capital undertakings are not in every case completely enhanced. So they have shown that value can be maximized through lifetime cost savings and increased functionality.

To solve these defects, this paper establishes a model of costing and scheduling based on the information and data from the project sources of the EUC project in Malaysia by implementing VE technique. The objective of this study is to optimize the overall costs of the EUC project in Malaysia and building the MEDS project specifically.

The remainder of this paper is organized as follows: Section 2 introduces the methodology of the study. Section 3 describes the result and discussion, and section 4 is the conclusion of the research.

\section{METHODOLOGY}

\subsection{Research procedure}

The procedure comprises a number of steps from the beginning until the end of the research. The first step is the data collection process. The data will be collected from projects on costing and scheduling of Energy Infrastructure development distribution at the EUC in Malaysia. A project of designing a building for distributions in a conventional way using Value Engineering processes.

There is a multi-step process for Value Engineering presented in this study (Figure 3) [5]. A preliminary step (VE0 is the arrangement and arranging of the extension. In this manner, limitations and goals of the VE exertion are explained. The first step (VE-1) depicts the data procurement, keeping in mind the end goal to clear up on the difficulties and destinations. Along these lines, applicable foundation data is accumulated, and client necessities are inferred. The next step (VE-2) includes a utilitarian investigation of the item in light of basic data (e.g., illustrations, costs, amounts) [30]. Inside this progression, capacities are characterized and depicted by a functioning verb and quantifiable thing. Against this foundation, the significance of capacities is surveyed, which might be bolstered by various systems given by writing. These techniques cover the function analysis system technique (FAST), Pareto-analysis, cost-to-function analysis, and furthermore [33]. This progression closes with a characterized and archived number of territories that give the best chance to enhancements.

VE-3 centers on the generation of thoughts for the achievement of capacities by various elective approaches. Subsequently, imagination strategies (e.g., conceptualizing, brainwriting) are utilized. Because of the inferred thoughts, the fourth step (VE-4) centers around the talk and appraisal of the thoughts or even options with an appropriate assessment procedure (e.g., score assessment). VE-5 centers on the improvement of thoughts to sound choices that are displayed to leaders. On the other hand, the options of VE-4 are additionally pointed by point to a proposition. The last step (VE-6) manages the introduction and execution of the directed options. Furthermore, Haskins [5] indicates out the significance check the objective accomplishment. Figure 4 shows the summarization process of Value Engineering.

The idea of objective setting is applicable to outline choices in development, as a customer's prerequisites may change, particularly amid the beginning times of a project. Value Engineering strategies empower the project members to distinguish the objective's best qualities and determine reasonable answers to satisfy the customer's necessities [21].

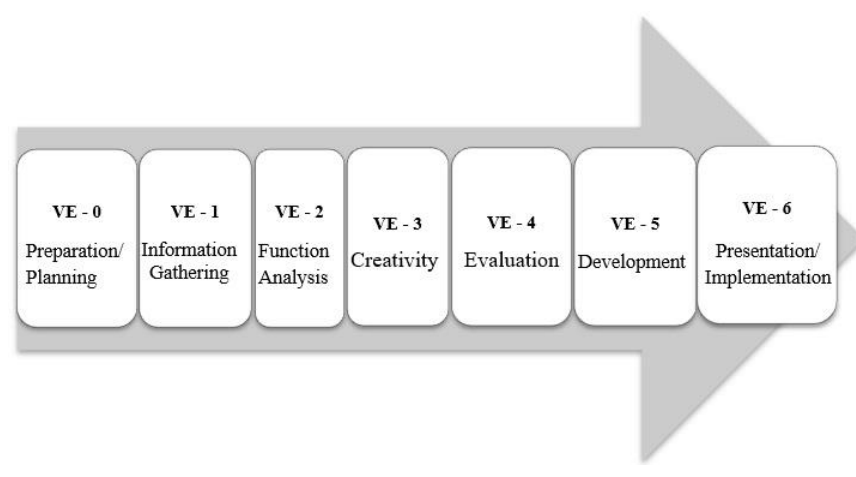

Figure 4. Process of Value Engineering [5]

For the data analysis method, another step will be taken into consideration. The data analysis method will be the comparison of the implementation of Value Engineering at Energy Company on project costing and scheduling and gives alternatives by using the seven processes of using Value Engineering.

\subsection{Data collection}

The data is collected from the project of the Energy Utility Company (EUC) in Malaysia, and as the objective of this research seeks to analyze and explore the effects of Value Engineering in optimizing projects' cost for energy infrastructure asset development. The EUC is selected as Malaysia's largest electricity utility. One of Malaysia's Electricity Supply Industry (MESI) goals is to ensure the economic viability of the EUC in Malaysia based on the fair industrial price of electricity [34]. The EUC in Malaysia is now in the midst of broadening its global presence. Their generation, transmission, and distribution businesses make them one of the few companies in the world that work through the whole value chain of electricity [35]. So, depending on this, the researchers will explore the effects of a specific energy infrastructure asset development and collect data from a construction project in Malaysia on project costing and scheduling by calculating the entire requirement needed for designing a building for distribution energy infrastructure. In the beginning, every single component of that special building (Energy infrastructure) will be evaluated and compare it with a regular building. The next step is running Value Engineering 
for all of the components of the building. This begins with brainstorming, which means finding alternatives when it is needed.

\subsection{Data analysis}

As this project is a case study base analysis, there are different techniques to analyze a case study data, such as explanation building, time-series analysis, pattern matching, cross-case synthesis, and logic models [36]. The case study in this project implies an explanation building using the created models of costing and scheduling based on the information and data from the project sources of the Energy Utility Company in Malaysia.

For analyzing the data, the cost and schedule of the Energy infrastructure construction distribution have been checked Depending on the construction fundamentals, the case is going to be divided into different stages and components: designing Foundations, walls, roof, finishing, and a few more elements on the construction parts. The cost of each step will be identified typically. Then Value Engineering will be conducted to recognize and function of the case study and measure its value. The next step is a comparison, a comparison will be performed as it is described in the data collection section and depending on the results, and the need of implementing Value Engineering in this crucial field (Energy Infrastructure Asset Development) will be shown. Then comparing the conventional preparation of cost estimation and scheduling of energy infrastructure distribution (the project) will be given in a conventional way by using and implementing Value Engineering processes, objectives, risks, alternatives in Energy Infrastructure as it is one of the most crucial fields that need it. Table 2 shows how to analyze case study data by explanation building technique.

Table 2. Description of analyzing case study by explanation building technique

\begin{tabular}{|c|c|}
\hline Steps & Description \\
\hline $\begin{array}{l}\text { Collected } \\
\text { data }\end{array}$ & $\begin{array}{l}\text { The data was collected from the Energy Utility } \\
\text { Company (EUC) project in Malaysia. }\end{array}$ \\
\hline $\begin{array}{l}\text { Study the } \\
\text { case }\end{array}$ & $\begin{array}{c}\text { Three components of the buildings have been } \\
\text { selected based on the room sizes, ceiling, and } \\
\text { painting }\end{array}$ \\
\hline $\begin{array}{l}\text { Show the } \\
\text { alternatives }\end{array}$ & $\begin{array}{l}\text { 1- Reducing the size of the rooms. } \\
\text { 2- Changing the type of paint. } \\
\text { 3- Changing the amount of the pained walls. }\end{array}$ \\
\hline $\begin{array}{l}\text { Replacing } \\
\text { with new } \\
\text { alternatives }\end{array}$ & $\begin{array}{l}\text { 1- The room size that was } 4 \times 4 \times 2.7 \text { meters is } \\
\text { reduced to } 2 \times 3 \times 2.7 \text { meters. } \\
\text { 2- Plaster and emulsion paint replaced by } \\
\text { normal paint. } \\
\text { 3- Reducing the painting area of the wall from } \\
1.5 \text { meters to } 1 \text { meter. }\end{array}$ \\
\hline $\begin{array}{l}\text { Comparing } \\
\text { the cost }\end{array}$ & $\begin{array}{l}\text { The cost before and after presenting the } \\
\text { alternatives has been compared, and the more } \\
\text { suitable cost (the less one) has been selected }\end{array}$ \\
\hline $\begin{array}{l}\text { Comparing } \\
\text { the quality }\end{array}$ & $\begin{array}{l}\text { The quality of materials before and after } \\
\text { presenting the alternatives has been compared }\end{array}$ \\
\hline
\end{tabular}

\section{RESULTS AND DISCUSSION}

The research was done on Energy Infrastructure Asset Development and Implementing VE in Energy Infrastructure Asset Development. The EUC in Malaysia is selected as Malaysia's largest electricity utility to collect data, and specifically, the design and construction of the main intake substation (MEDS) building belonging to the EUC are selected.

\subsection{Implementation of value engineering in projects of the energy utility company in Malaysia}

The data for the objective of this project collected from the Electrical Substation Design (Type of Building) Section Distribution, which is introduced the latest standards for substation design electricity (the type of building) in the Distribution Division, the EUC in Malaysia, including 11/0.4kV Electrical Substation, 11kV Main Switch Station, $11 \mathrm{kV}$ Main Switch Station with 11 / 0.4kV transformer, Main Switch Station $33 \mathrm{kV}$ and Main Distribution Substation $33 / 11 \mathrm{kV}$. Therefore, the focus of this project is on the building's Main Electric Distribution Station (MEDS), the Main Distribution Sub-station (MDS), and Main Switching Station (MSS). Here are some important details about the EUC in Malaysia substation categories, type, and design.

The Main Electric Distribution Station (MEDS) is the $132 \mathrm{kV}$ or $275 \mathrm{kV}$ interconnection point to the distribution network. At the MEDS, standard voltage transformations are:(-275/132kV-132/33kV-132/11kV). While the Main Distribution Sub-station (MDS) normally applies to $33 \mathrm{kV}$ for connecting $33 \mathrm{kV}$ networks to $11 \mathrm{kV}$ networks. It enables power injection into the $11 \mathrm{kV}$ network through a standardized $33 / 11 \mathrm{kV}$ transition. The main switching station (MSS) is built at $33 \mathrm{kV}, 22 \mathrm{kV}$, and $11 \mathrm{kV}$ to serve the following function

1. Supply of a specialist bulk consumer $(33 \mathrm{kV}, 22 \mathrm{kV}$, $11 \mathrm{kV})$.

2. To provide injection or transfer of bulk power from a MEDS/MDS to a load center for further localization.

In this case study, the objective of the Project Engineering and Design stage is to review the design requirement of the MEDS and ensure that the proposed project requirements are adequate, complete, and consistent with the Energy Utility Company's Planning Division requirements.

The substation building design shall comply with the Building By-Laws, Design Codes, and Standards and shall conform to the Energy Utility Company requirements. The building shall be designed as a stand-alone building and constructed on the ground level. The building shall be fit to house various high voltage transformers, electrical control equipment, protection relays, switchgear, communication equipment, battery, and other ancillaries' equipment.

\subsubsection{Typical room sizes}

The substation building shall be designed to provide convenient access for the EUC to enter, operate, and carry out maintenance work of the substation at any time. For a typical one and a half $\left(\begin{array}{ll}1 & 1 / 2\end{array}\right)$ story $132 \mathrm{kV}$ control building, the minimum room sizes are summarized as in Table 3 .

\subsubsection{Size of the power substation and main switch station}

The size of the electric substation site and the main switch station alone should comply with the requirements rear area and front area (setback and frontage) of the local authority. The site needs to be fitted with a 6 "high-grade crusher runs coated with 2" mm premix/cement.

3.1.3 Basic building structure of substation $11 / 0.4 \mathrm{kV} \& 11 \mathrm{kV}$

The foundation of the Electric Substation is built on the ground state of the site, if necessary, it should be done. All 
civil designs need to be done and approved by Professional Civil Engineers. 1 "thick 1: 1 cement sand screen bedding should be spaced on the ground beam after this layer dry, bituminous strips felt stretched along with liquefied bitumen. Design loads (design load) must comply with $10 \mathrm{kN} / \mathrm{sq} . \mathrm{m}$ criteria with equipment, as shown in Table 4.

Table 3. Typical room sizes for substation building

\begin{tabular}{|c|c|c|c|c|}
\hline \multirow[b]{2}{*}{ No } & \multirow[b]{2}{*}{ Area } & \multirow{2}{*}{$\begin{array}{l}\text { Floor } \\
\text { Level }\end{array}$} & \multicolumn{2}{|c|}{ Min Room Size } \\
\hline & & & $\begin{array}{c}\text { Floor } \\
(\mathbf{m})\end{array}$ & $\begin{array}{c}\text { Height } \\
(\mathbf{m})\end{array}$ \\
\hline 1 & $\begin{array}{c}\text { 33kV Cable Cellar } \\
\text { Area }\end{array}$ & Ground & $18 \times 7$ & 2.7 \\
\hline 2 & $\begin{array}{l}\text { 132kV Cable Cellar } \\
\text { Area Ground } 20\end{array}$ & Ground & $20 \times 13$ & 2.7 \\
\hline 3 & Utility Room & Ground & $4 \times 3$ & 2.7 \\
\hline 4 & Toilet & Ground & $4 \times 3$ & 2.7 \\
\hline 5 & $\begin{array}{c}\text { 132kV/33kV Control \& } \\
\text { Relay Room }\end{array}$ & 1st. & $20 \times 13$ & 3.5 \\
\hline 6 & 33kV GIS Room & 1 st. & $18 \times 7$ & 3.5 \\
\hline 7 & Communication Room & 1 st. & $6 \times 4$ & 3.5 \\
\hline 8 & Battery Room & 1 st. & $6 \times 5.5$ & 3.5 \\
\hline 9 & LVAC Room & 1st. & $6 \times 3.5$ & 3.5 \\
\hline
\end{tabular}

Table 4. Design loads (Source: Guidebook standard electrical substation design)

\begin{tabular}{ccc}
\hline Type of Room & Equipment & Weight \\
\hline Changing room & Transformer & $7,000 \mathrm{~kg}$ \\
Tool-suite room & Vacuum circuit breaker & 1,000 kg per VCB \\
& (VCB) & panel \\
Tool-suite room & Ring Main Unit (RMU) & $1,000 \mathrm{~kg}$ per RMU \\
\hline
\end{tabular}

Typically, all walls need to be built with Well-Burnt-Red Clay Bricks with 1: 3 cement sand mortar. The perimeter wall is $230 \mathrm{~mm}$ thick, the wall between the appliance and the room the transformer is $230 \mathrm{~mm}$ thick and $2100 \mathrm{~mm}$ high. All walls need to be strengthened with expanded metal (Exmet) on every four layers. The clearance between the bottom of the beam and the bottom of the trench is a minimum of $600 \mathrm{~mm}$.

\subsubsection{Electrical installation fences, doors, and window}

For the electrical Installation Fences, Doors and Window 11 / $0.4 \mathrm{kV} \& 11 \mathrm{kV} \mathrm{1,000} \mathrm{kg} \mathrm{per} \mathrm{RMU,} \mathrm{the} \mathrm{fence} \mathrm{for} \mathrm{a} \mathrm{Private}$ Electric Substation can be excluded in the appropriate area and replaced with a $150 \mathrm{~mm}$ (width) x $450 \mathrm{~mm}$ (height) concrete crane to mark the substation site electricity. The electric substation fence door is replaced with removable barriers, so the entrance to the electrical substation is unobstructed.

Table 5. Design of electrical substation doors

\begin{tabular}{ccc}
\hline Room Type & Size & Door Type \\
\hline $\begin{array}{c}\text { Tool-suite } \\
\text { room }\end{array}$ & $\begin{array}{c}1500 \mathrm{~mm}(\mathrm{~W}) \mathrm{x} \\
3000 \mathrm{~mm}(\mathrm{H})\end{array}$ & $\begin{array}{c}\text { F.R.P Composite Door with } \\
\text { anti-vermin stainless steel } \\
\text { netting is installed inside the } \\
\text { door. }\end{array}$ \\
$\begin{array}{c}\text { Container } \\
\text { room }\end{array}$ & $\begin{array}{c}2400 \mathrm{~mm}(\mathrm{~W}) \mathrm{x} \\
3000 \mathrm{~mm}(\mathrm{H})\end{array}$ & $\begin{array}{c}\text { F.R.P Composite Door with } \\
\text { anti-vermin stainless steel } \\
\text { netting is installed inside the } \\
\text { door. }\end{array}$ \\
\hline
\end{tabular}

For Continuing Electric Substations, removable barriers need to be installed 3 meters at the door, the tooling room, and the transformer room so that the entrance to the electrical substation is unobstructed and the electrical substation windows are constructed according to the following specifications: Wind Stone (Ventilation Cement Block) with stainless steel anti vermin netting with frame stainless steel mounted outside the window. Electrical substation doors are constructed according to the specifications shown in Table 5.

\subsubsection{Building design guidelines \& land features}

For 33kV Main Switching Station (MSS) \& Main Distribution Sub-station (MDS) 33/11kV Stand Alone:

1. Type of MDS/MSS design stand alone is $1 \frac{1}{2}$ level with cable cellar.

2. The design features of the MDS/MSS building standalone.

Table 6 shows the design features MDS/MSS and the requirement of building and land size. The typical Storey of MSS $33 \mathrm{kV}$ Standard Building is shown in Figure 5. Figure 6 represents the main distribution stations of MDS.

Table 6. Design features MDS/MSS and building and land size requirement

\begin{tabular}{|c|c|}
\hline Building MDS & Building MSS \\
\hline$* 11 / 2$ level with cable cellar & $* 11 / 2$ level with cable cellar \\
\hline $\begin{array}{l}\text { * Placing tool rooms switch, } \\
\text { control and battery on level } 1\end{array}$ & $\begin{array}{l}\text { * Placing tool rooms switches, } \\
\text { controls, and batteries on the } \\
\text { floor } 1\end{array}$ \\
\hline $\begin{array}{l}* \text { The cables are housed in a } \\
\text { cable cellar (ground floor) }\end{array}$ & $\begin{array}{l}\text { * The cables are housed in a } \\
\text { cable cellar (ground floor) }\end{array}$ \\
\hline $\begin{array}{l}* \text { Place the transformer space } \\
* \text { Building size: } 24.5 \mathrm{~m} \times 26 \mathrm{~m}\end{array}$ & * Building size: $14 \mathrm{~m} \times 14 \mathrm{~m}$ \\
\hline $\begin{array}{c}\text { * Sufficient land size, i.e., at } \\
\text { least } 45 \mathrm{~m} \times 45 \mathrm{~m}\end{array}$ & $\begin{array}{c}\text { * Sufficient land size, i.e., at } \\
\text { least } 30 \mathrm{~m} \times 30 \mathrm{~m}\end{array}$ \\
\hline
\end{tabular}

\subsection{Implementation of value engineering}

\subsubsection{Information phase}

The researchers started by collecting and gathering all the required information from the EUC construction project in the previous sections. Then the current conditions of the project have been defined after the identification of the goal of the study. In this part, the information gathered from the layout plan of the project. Also, the details recorded to avoid going beyond the boundaries of requirements that the MEDS guideline has provided.

\subsubsection{Function phase}

This process will evaluate the project 's purpose from the higher to the lower order of the feature. To optimize the cost, and to carry the primary feature of the project, the lower-order function should be suggested to a few alternatives. Depending on Eq. (2), we can define the value of the product/design:

$$
\text { Value }=\frac{\text { Function }+ \text { Quality }}{\text { Cost }}
$$

where,

function $=$ performance of a specific work of a design/an item.

Quality = Owner's or customer's needs, desires, and expectations.

Cost $=$ Life cycle cost of a product $/$ an item .

Based on the quotation above, when the cost increase to raise the function and quality of the product, the value will decrease. Instead, if the cost reduces, but the function and the 
quality are remained or increased, the value will increase. On the other hand, if the cost does not improve the quality of a product/design or its performance, then the value will decrease. The function analysis of the project will be optimized to the lower cost. Few alternatives will be suggested so that it can still carry the main function of the project.

In Value Engineering, one of the function analysis methods is the Function Analysis System Technique (FAST) method. Figure 7 shows the FAST diagram, which starts from the function of the highest order and will be broken apart by analyzing the function itself. The first function will be shown how to carry out the function itself. Secondly, the second function will be progressed. This diagram presents the function of why from right to left and how from left to right.

\subsubsection{Creation phase}

In the creative phase, the possible ideas will be brainstormed for the objectives of the current case study to build MEDS Building of the EUC in Malaysia. Later, from the designs, the alternatives will be proposed, as shown in Table 7. Before deciding on the alternatives, a few questions will be asked, whether the design shall be changed or not? Such as:

1. Does the size of the rooms (Toilets) need to be $4 \times 3$ $\mathrm{x} 2.7$ ?

2. Does the ceiling need to be Plaster emulsion tiles?

3. Does the proposed painting is necessary with this high-cost performance (high price)?

As the MEDS building construction is critical in terms of its usage for producing energy and electricity, this indicates that the building will carry a lot of heavy machines and will be facing many vibrations during a lifetime. The components of such a structure must be parallel with the requirements of the existing guideline of the project, which is highlighted by the specialized team of the EUC in Malaysia. The guidance of the current project sets several conditions and specifications for the materials used in this project. It is very hard to find some creative alternatives to increase the quality and decrease the cost to enhance the outcome of the project.

It is tough to put options to work on because it will reduce the safety of the project. So the first step is to propose to reduce the area of the rooms. For the second alternative, the celling of the building could be covered by ordinary painting instead of Plaster and emulsion paint finish. For the third alternative, the paint of the walls shall be reduced to $1 \mathrm{~m}$ high only rather than the gloss paint up to $1.5 \mathrm{~m}$ high (from floor level). Table 7 shows an example of the generated alternatives.

Table 7. Example of generated alternatives

\begin{tabular}{|c|c|c|c|}
\hline Objective & Base & Alternatives & \\
\hline Room sizes & 4 × 3 × 2.7 (Big) & $\begin{array}{c}2 \times 3 \times 2.7 \\
\text { (smaller) }\end{array}$ & $\begin{array}{r}1^{\text {st }} \\
\text { Alt. }\end{array}$ \\
\hline Ceiling & $\begin{array}{c}\text { Plaster and emulsion } \\
\text { paint }\end{array}$ & $\begin{array}{l}\text { Only Normal } \\
\text { Paint }\end{array}$ & $\begin{array}{l}2^{\text {nd }} \\
\text { Alt. }\end{array}$ \\
\hline Painting & $\begin{array}{l}\text { Paint up to } 1.5 \mathrm{~m} \text { high } \\
\text { of walls from floor }\end{array}$ & $\begin{array}{l}\text { paint up to } 1.0 \\
\text { m high only }\end{array}$ & $\begin{array}{r}3^{\text {rd }} \\
\text { Alt. }\end{array}$ \\
\hline
\end{tabular}

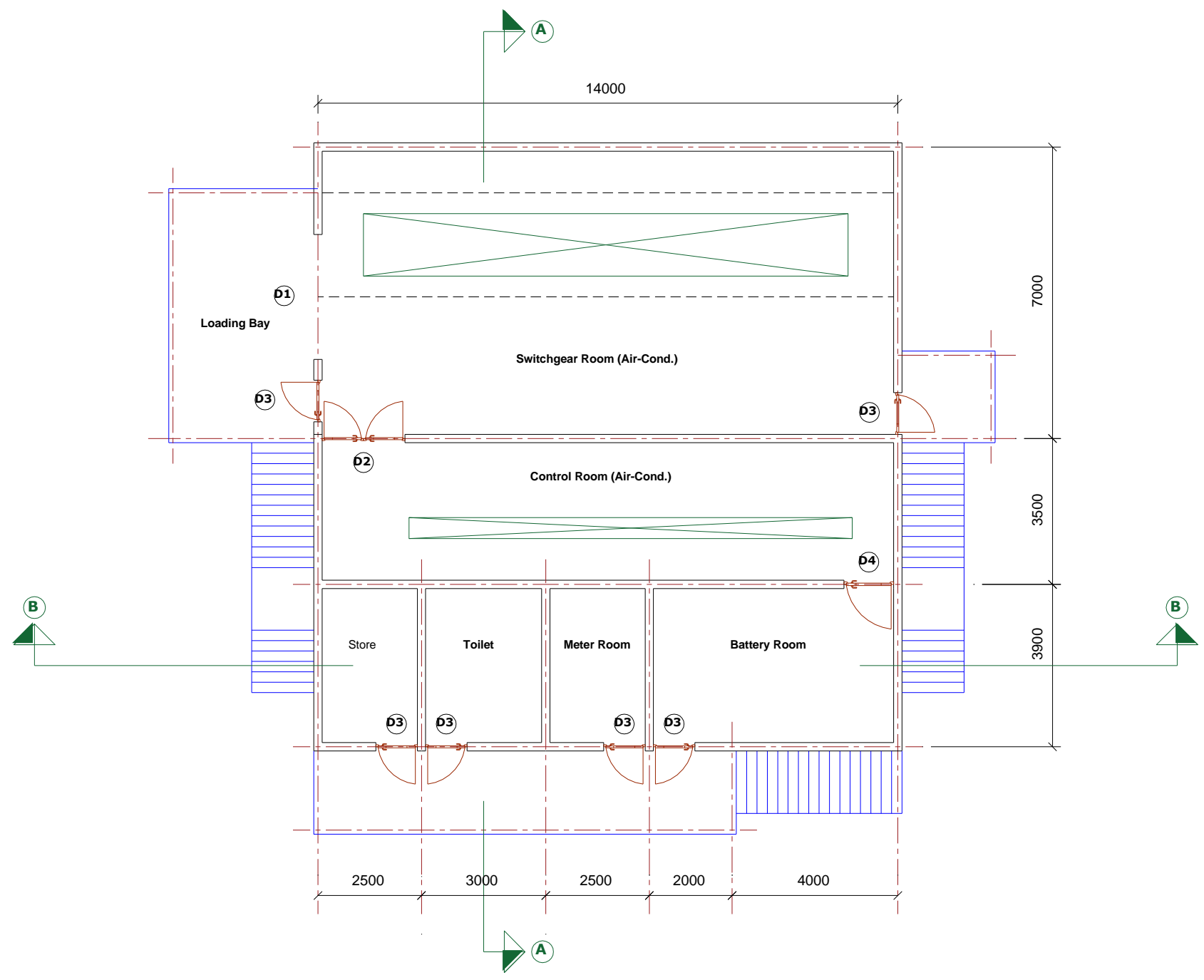

Figure 5. Typical Storey of MSS 33kV standard building 


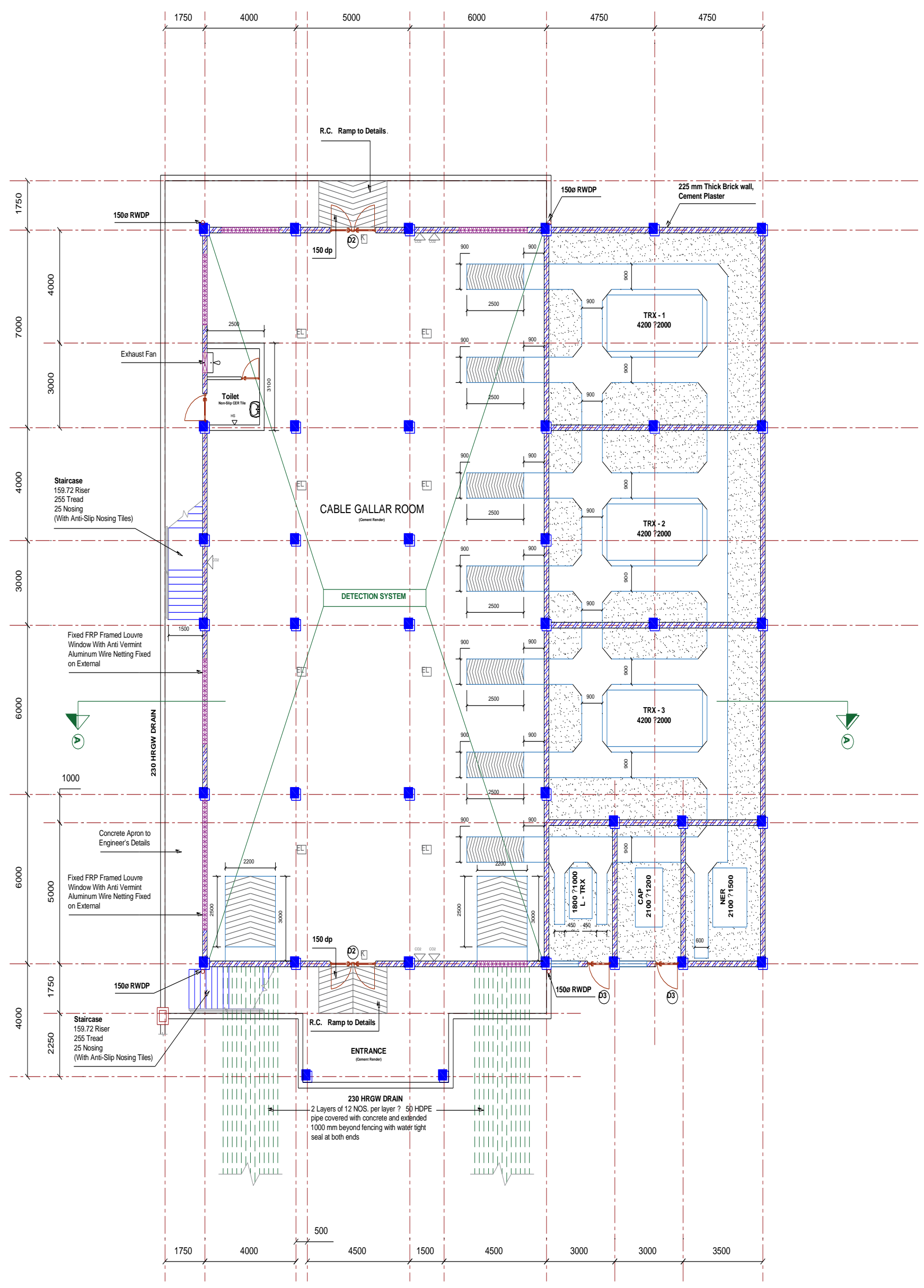

Figure 6. Main Distribution Stations (MDS) $33 / 11 \mathrm{Kv}$ 


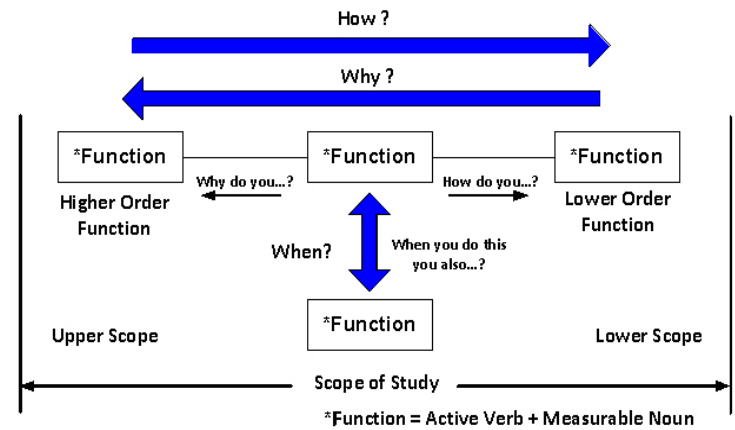

Figure 7. Function analysis system technique (FAST) diagram

\subsubsection{Evaluation}

Evaluation Phase is where each alternative was assessed according to the Value Engineering equation, as explained in the previous section. The value was measured in this study by multiplying the risk factor, which consists of the cost index and the design appearance.

This means that a formal assessment process was conducted to select those ideas that provide the potential for value enhancement while delivering the purpose of the projects and taking into account performance requirements and resource limitations.

The alternatives were evaluated according to the VE methodology, which is getting the higher performance and lower cost. Eq. (3) shows the value index calculation:

$$
\text { Value Index }=\frac{\text { Function }}{\text { Cost }}
$$

This part was essential to be able to prepare the information for the next step, as it is shown in Figure 8. The next step will be significant because it is the evaluation of the collected data with the new alternatives.

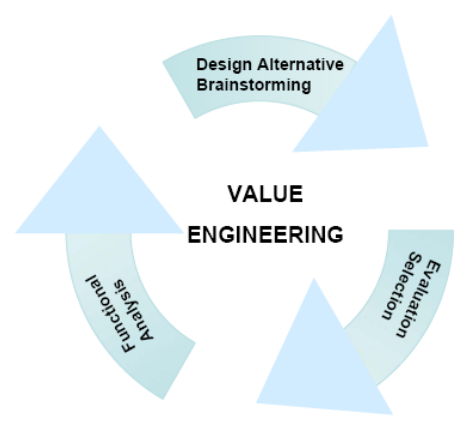

Figure 8. The most three practical phase of value engineering
Depending on the proposed alternatives and applying them to the whole project, the cost of the project will be deceased, and the performance attribute will be delivered in a shorter period of time because it takes less time to: Build smaller spaces, use fewer paint spaces (walls), and not to do the unnecessary works, such as putting plasters and emulsion paint. Thus, Value Engineering will be a great tool to increase the value, decrease the cost, and schedule of the completed project. The details of the first alternative are shown in Table 8.

According to the generated alternative above, the area of the building is $874 \mathrm{~m}^{2}$, but after reducing the size of the rooms, it became $724.5 \mathrm{~m}^{2}$, which means $149.5 \mathrm{~m}^{2}$ had been decreased. Based on that, $17.1 \%$ of the overall cost of the building will be decreased. Thus, the first alternative was the most important alternative because it relates to the overall performance and cost of the building. Table 9 represents the percentage of reduction amount after reducing the overall size of the building.

Regarding the second alternative, the first-floor ceiling is $874 \mathrm{~m}^{2}$, and the second-floor ceiling is $874 \mathrm{~m}^{2}$. So, the total ceiling that needs to be painted is $1748 \mathrm{~m}^{2}$. The plaster painting price of $1 \mathrm{~m}^{2}$ is RM5.49 based on the guideline of the EUC in Malaysia. After reducing the overall area of the building, the ceiling will also be decreased. The ceiling for each floor became $724.5 \mathrm{~m}^{2}$, which means the overall ceiling after reduction is $1449 \mathrm{~m}^{2}$. Furthermore, our aim is to reduce the cost of the painting since the ceiling does not need that kind of special quality of the painting. The alternative for the ceiling is a normal painting that priced RM2 per $\mathrm{m}^{2}$. Table 10 represents the detail of the second alternative.

So, the saved amount is RM6698.52 for the second alternative, and the result indicates that $69.8 \%$ of the total cost for ceiling painting will be saved.

Regarding the third alternative, the first step is calculating the dimension of the wall on both floors. Depending on the guidance of the EUC in Malaysia, the building has two different types of walls. The ground-floor room height is $2.7 \mathrm{~m}$ while the first-floor rooms are $3.5 \mathrm{~m}$ height. To calculate the dimensions of the walls, the researchers have used the given information that provided it in the guidance of the EUC in Malaysia. Table 11 represents the actual wall dimensions of the whole building and the dimensions of the alternative wall after reducing the size of the rooms.

Table 12 represents the dimensions of the walls that need to be painted (Height $1.5 \mathrm{~m}$ ) based on the guideline of the EUC in Malaysia. Also, based on the first alternative, it represents the reduced size that needs to be painted (1.5m height).

Table 13 shows the dimensions of the walls that should be painted before and after applying the first and third alternatives. According to the result of the third alternative, RM 1103.49 will be saved, which equals saving $41.6 \%$.

Table 8. Details of the alternative 1

\begin{tabular}{ccccc}
\hline \multirow{2}{*}{ No } & \multirow{2}{*}{ Area } & Floor Level & \multicolumn{2}{c}{ Room Size } \\
\cline { 4 - 5 } & & Floors $(\mathbf{m}) \times$ Height $(\mathbf{m})$ & Alternative Floors $(\mathbf{m}) \mathbf{x}$ Height $(\mathbf{m})$ \\
\hline $\mathbf{1}$ & 33kV Cable Cellar Area & Ground & $18 \times 7 \times 2.7$ & $15 \times 7 \times 2.7$ \\
$\mathbf{2}$ & 132kV Cable Cellar Area Ground 20 & Ground & $20 \times 13 \times 2.7$ & $17 \times 13 \times 2.7$ \\
$\mathbf{3}$ & Utility Room & Ground & $4 \times 3 \times 2.7$ & $3 \times 3 \times 2.7$ \\
$\mathbf{4}$ & Toilet & Ground & $4 \times 3 \times 2.7$ & $2 \times 3 \times 2.7$ \\
$\mathbf{5}$ & $132 \mathrm{kV} / 33 k V$ Control \& Relay Room & 1 st. & $20 \times 13 \times 3.5$ & $17 \times 13 \times 3.5$ \\
$\mathbf{6}$ & 33kV GIS Room & 1 st. & $18 \times 7 \times 3.5$ & $15 \times 7 \times 3.5$ \\
$\mathbf{7}$ & Communication Room & 1 st. & $6 \times 4 \times 3.5$ & $4 \times 4 \times 3.5$ \\
$\mathbf{8}$ & Battery Room & 1 st. & $6 \times 5.5 \times 3.5$ & $5 \times 5.5 \times 3.5$ \\
$\mathbf{9}$ & LVAC Room & 1 st. & $6 \times 3.5 \times 3.5$ & $4 \times 3.5 \times 3.5$ \\
\hline
\end{tabular}


Table 9. The detail of the reduction amount of the room sizes of the building

\begin{tabular}{cccc}
\hline $\begin{array}{c}\text { Size of the building } \\
\left(\mathbf{m}^{\mathbf{2}}\right)\end{array}$ & $\begin{array}{c}\text { Size of the building after implementing VE } \\
\left(\mathbf{m}^{\mathbf{2}}\right)\end{array}$ & $\begin{array}{c}\text { Reduced size } \\
\left(\mathbf{m}^{\mathbf{2}}\right)\end{array}$ & $\begin{array}{c}\text { Reduction amount in percentage } \\
(\%)\end{array}$ \\
\hline 874 & 724.5 & 149.5 & 17.1 \\
\hline
\end{tabular}

Table 10. Details of the second alternative

\begin{tabular}{cccc}
\hline & Area $\left(\mathbf{m}^{\mathbf{2}}\right)$ & Painting Price $(\mathbf{R M})$ per $\mathbf{~ m}^{\mathbf{2}}$ & Total Price (RM) \\
\hline Before Implementing VE & 1748 & 5.49 (Plaster) & 9596.52 \\
After Implementing VE & 1449 & 2.00 (Normal) & 2898 \\
\hline
\end{tabular}

Table 11. The actual wall dimensions of the whole building and the dimensions of the alternative walls after reducing the size of the rooms

\begin{tabular}{ccccc}
\hline \multirow{2}{*}{ No. } & \multirow{2}{*}{ Area } & \multirow{2}{*}{ Floor Level } & \multicolumn{2}{c}{ Dimension } \\
\cline { 4 - 5 } & & Wall Dimension (m) & Alternative 1 Wall Dimension (m) \\
\hline $\mathbf{1}$ & 33kV Cable Cellar Area & Ground & 135 & 118.8 \\
$\mathbf{2}$ & 132kV Cable Cellar Area Ground 20 & Ground & 178.2 & 162 \\
$\mathbf{3}$ & Utility Room & Ground & 37.8 & 32.4 \\
$\mathbf{4}$ & Toilet & Ground & 37.8 & 27 \\
$\mathbf{5}$ & $132 \mathrm{kV} / 33 \mathrm{kV}$ Control \& Relay Room & 1 st. & 231 & 210 \\
$\mathbf{6}$ & 33kV GIS Room & 1 st. & 175 & 154 \\
$\mathbf{7}$ & Communication Room & 1 st. & 70 & 56 \\
$\mathbf{8}$ & Battery Room & 1 st. & 80.5 & 73.5 \\
$\mathbf{9}$ & LVAC Room & 1 st. & 66.5 & 52.5 \\
\hline
\end{tabular}

Table 12. The dimensions of the walls need to be pained

\begin{tabular}{|c|c|c|c|c|c|}
\hline \multirow[b]{2}{*}{ No } & \multirow[b]{2}{*}{$\begin{array}{l}\text { Floor } \\
\text { Level }\end{array}$} & \multicolumn{2}{|c|}{ Wall Dimension $\left(\mathbf{m}^{2}\right)$} & \multicolumn{2}{|c|}{ Alternative Wall Dimension $\left(\mathbf{m}^{2}\right)$} \\
\hline & & $\begin{array}{c}\text { [(Length + Width) X } \\
\text { Height }]\end{array}$ & $\begin{array}{c}\text { [(Length + Width) X } 1.5 \\
\mathrm{~m}]\end{array}$ & $\begin{array}{c}\text { [(Length + Width) } X \\
\text { Height }]\end{array}$ & $\begin{array}{c}{[(\text { Length + Width) X } 1.5} \\
\mathrm{m}]\end{array}$ \\
\hline 1 & Ground & 135 & 75 & 118.8 & 66 \\
\hline 2 & Ground & 178.2 & 99 & 162 & 90 \\
\hline 3 & Ground & 37.8 & 21 & 32.4 & 18 \\
\hline 4 & Ground & 37.8 & 21 & 27 & 15 \\
\hline 5 & 1st. & 231 & 99 & 210 & 90 \\
\hline 6 & 1st. & 175 & 75 & 154 & 66 \\
\hline 7 & 1st. & 70 & 30 & 56 & 24 \\
\hline 8 & 1st. & 80.5 & 34.5 & 73.5 & 31.5 \\
\hline 9 & 1st. & 66.5 & 28.5 & 52.5 & 22.5 \\
\hline Total & & & 483 & & 423 \\
\hline
\end{tabular}

Table 13. The dimensions of the walls before and after applying the first and third alternatives

\begin{tabular}{|c|c|c|c|c|c|}
\hline \multicolumn{2}{|c|}{ Wall Size $\left(\mathbf{m}^{2}\right)$} & \multicolumn{2}{|c|}{ Alternative 1 for Wall Size $\left(\mathrm{m}^{2}\right)$} & \multicolumn{2}{|c|}{ Alternative 3 (Painting $1 \mathbf{~ m}^{2}$ ) } \\
\hline $\begin{array}{l}\text { Walls to be painted } \mathrm{x} \\
1.5\left(\mathrm{~m}^{2}\right)\end{array}$ & $\begin{array}{c}\text { COST } \\
\text { Wall size X RM } \\
5.49\end{array}$ & $\begin{array}{l}\text { Walls to be painted } \mathrm{x} \\
1.5\left(\mathrm{~m}^{2}\right)\end{array}$ & $\begin{array}{c}\text { COST } \\
\text { Wall size X RM } \\
5.49\end{array}$ & $\begin{array}{l}\text { Walls to be painted } \\
\qquad\left(1 \mathrm{~m}^{2}\right)\end{array}$ & $\begin{array}{c}\text { COST } \\
\text { Wall size X RM } \\
5.49\end{array}$ \\
\hline 483 & 2651.67 & 423 & 2322.27 & 282 & 1548.18 \\
\hline
\end{tabular}

\subsubsection{Development}

For the cost reduction, the study focused on two essential points (second and third alternative). The reduced cost percentage for the painting of the ceiling ( $2^{\text {nd }}$ Alternative) is $69.8 \%$, while the reduced cost percentage of the walls that need to be painted ( $3^{\text {rd }}$ Alternative) will be $41.6 \%$.

\section{CONCLUSION}

VE has been implemented in this study as a significant tool for reducing the cost of the project without compromising the quality of the materials. The building of this study is a special type of building that needs to take the quality of each component into consideration before producing the final performance. In this study, three alternatives have been selected to decrease the cost of the project. The first alternative was to reduce the overall area of the rooms of the building. Thus, the first alternative was the most important alternative because it relates to the overall performance and cost of the building. Based on the result of the first alternative, $17.1 \%$ of the overall cost of the building will be decreased. The second alternative was about the ceiling painting, and the Plaster painting was replaced by normal painting. The saved amount was RM6698.52, and the result indicates that $69.8 \%$ of the total cost for ceiling painting will be saved. The third alternative was about painting up to $1.5 \mathrm{~m}$ high walls from the floor. According to the result, RM1103.49 will be saved, which equals saving $41.6 \%$. The findings of this research will be useful for engineers, scholars, constructors, as it adds to the literature by evaluating the implementation of Value Engineering in the construction industry and adding on the 
cost optimization of energy infrastructure asset development. Finally, its recommended for future studies to implement our model with supply chain management and building information modeling (BIM) to other building projects and compare the result to ensure the outperformed model for cost optimization.

\section{REFERENCES}

[1] Gunarathne, A.S., Zainudeen, N., Perera, C.S.R., Perera, B.A.K.S. (2020). A framework of an integrated sustainability and value engineering concepts for construction projects. International Journal of Construction Management, 1-13. https://doi.org/10.1080/15623599.2020.1768624

[2] Zou, J. (2019). Construction and application analysis of construction project cost management information system based on value perspective. No. Icemit 1-5.

[3] Li, Y. (2018). Research on construction projects cost management. IOP Conference Series: Materials Science and Engineering, 394(3). https://doi.org/10.1088/1757899X/394/3/032057

[4] Sawan, R., Low, J.F., Schiffauerova, A. (2018). Quality cost of material procurement in construction projects. Engineering Construction Architectural Management, 25(8): 974-988. https://doi.org/10.1108/ECAM-042017-0068

[5] Haskins, C. (2010). INCOSE - International Council on System Engineering - Systems Engineering Handbook. No. Harvard.

[6] Xu, J., Lu, Y., Huang, L. (2016). Proceedings of the 22nd international conference on industrial engineering and engineering management 2015. Innovation and Practice in Industrial Engineering and Management (Volume 2), 383-391. https://doi.org/10.2991/978-94-6239-177-2

[7] Al-Yafei, E., Ogunlana, S., Oyegoke, A. (2017). Application of value engineering and life cycle costing techniques for offshore topside facility projects: Towards sustainability. SPE Kuwait Oil \& Gas Show and Conference, Kuwait. https://doi.org/10.2118/187638-ms

[8] Gohil, P., Patel, S. (2018). Review of value engineering in Indian construction industry. International Journal of Advanced in Management, Technology and Engineering Sciences, 8(III): 1080-1085.

[9] Usman, F., Jalaluddin, N.A., Hamim, S.A. (2018). Value engineering in building information modelling for cost optimization of renovation works: A case study. International Journal of Engineering \& Technology, 7(4): 431-435. https://doi.org/10.14419/ijet.v7i4.35.22856

[10] Park, C.S., Kim, H.J., Park, H.T., Goh, J.H., Pedro, A. (2017). BIM-based idea bank for managing value engineering ideas. International Journal of Project Management, 35(4): 699-713. https://doi.org/10.1016/j.ijproman.2016.09.015

[11] Othman, A.A.E., Abdelrahim, S.M. (2019). Achieving Sustainability through reducing construction waste during the design process: A value management perspective. Journal of Engineering, Design and Technology, 18(2): 362-377. https://doi.org/10.1108/JEDT-03-2019-0064

[12] Elsonoki, M.M., Yunus, R., Yunus, S.R., Hamid, A.R.A. (2020). The adoption of value engineering practices in the Libyan construction industry. IOP Conference Series:
Earth and Environmental Science, 498(1). https://doi.org/10.1088/1755-1315/498/1/012099

[13] Elsonoki, M.M., Yunus, R. (2020). Value engineering practices in the Libyan construction industry: A preliminary study. IOP Conference Series: Earth and Environmental Science, 498(1). https://doi.org/10.1088/1755-1315/498/1/012109

[14] Danso, H., Osei Kwadwo, R. (2020). Assessment of value engineering implementation in the Ghanaian construction sector. Journal of the Institution Engineers (India): $\quad$ Series $\quad \mathrm{A}, \quad$ 101(1): 7-17. https://doi.org/10.1007/s40030-019-00423-6

[15] Parakhiya, D., Patel, J. (2017). Application of value engineering in construction project: Case study on residential project in Ahmedabad. International Journal for Science Research \& Development, 5(2): 1890-1894.

[16] Rachwan, R., Abotaleb, I., Elgazouli, M. (2016). The influence of value engineering and sustainability considerations on the project value. Procedia Environmental Sciences, 34: 431-438. https://doi.org/10.1016/j.proenv.2016.04.038

[17] Yu, M., Robati, M., Oldfield, P., Wiedmann, T., Crawford, R., Nezhad, A.A., Carmichael, D. (2020). The impact of value engineering on embodied greenhouse gas emissions in the built environment: A hybrid life cycle assessment. Building and Environment, 168: 106452. https://doi.org/10.1016/j.buildenv.2019.106452

[18] Ali, K., Ahmed, A., Pandey, R.K. (2016). Concept of value engineering in construction industry. International Journal of Science and Research, 5(4): 1231-1237. https://doi.org/10.21275/v5i4.nov162492

[19] Mehta, C. (2020). Value engineering as an effective tool for construction projects: A review. No. 60, 1927-1936.

[20] Li, D., Li, Z., Zhang, Z. (2019). The study on the earthworks of green construction based on value engineering. IOP Conference Series: Earth and Environmental Science, 218(1). https://doi.org/10.1088/1755-1315/218/1/012024

[21] Leung, M.Y., Ng, S.T., Cheung, S.O. (2002). Improving satisfaction through conflict stimulation and resolution in value management in construction projects. Journal of Management in Engineering, 18(2): 68-75. https://doi.org/10.1061/(ASCE)0742597X(2002)18:2(68)

[22] Jaapar, A.; Maznan, N. A.; Zawawi, M. (2012). Implementation of value management in public projects. Procedia - Social and Behavioral Science, 68: 77-86. https://doi.org/10.1016/j.sbspro.2012.12.208

[23] Chen, W.T., Tsai, T.C., Liou, S.W., Shen, W.S. (2013). A simplified way of implementing value engineering for public works. In Applied Mechanics and Materials, 357360: 2925-2930 https://doi.org/10.4028/www.scientific.net/AMM.357360.2925

[24] El-Nashar, W.Y. (2017). Effect of drains coverings on environment by using value engineering. Alexandria Engineering Journal, 56(3): 327-332. https://doi.org/10.1016/j.aej.2017.05.013

[25] Rangelova, B.R.., McElligott, W.C. (2014). Value Management in Construction. Part of the Macmillan Building and Surveying Series Book Series (BASS). https://doi.org/10.1007/978-1-349-13350-5

[26] Jaapar, A. (2008). Value management study to the Malaysian construction industry. BEAN 2008 Conf. 
[27] Jaapar, A., Endut, I.R., Ahmad Bari, N.A., Takim, R. (2009). The impact of value management implementation in Malaysia. Journal of Sustainable Development, 2(2). https://doi.org/10.5539/jsd.v2n2p210

[28] Heralova, R.S. (2016). Possibility of using value engineering in highway projects. In Procedia Engineering, 164: 362-367. https://doi.org/10.1016/j.proeng.2016.11.631

[29] Lee, M.J., Lim, J.K., Hunter, G. (2010). Performancebased value engineering application to public highway construction. KSCE Journal of Civil Engineering, 14: 261-271. https://doi.org/10.1007/s12205-010-0261-y

[30] Behncke, F.G.H., Maisenbacher, S., Maurer, M. (2014). Extended model for integrated value engineering. Procedia Computer Science, 28: 781-788. https://doi.org/10.1016/j.procs.2014.03.093

[31] Lin, G.B., Shen, Q.P. (2010). Development of performance measurement framework for value management studies in construction. Construction Research Congress 2010. Innovation for Reshaping Construction Practice, Banff Alberta, Canada, pp. 10001009.

[32] Pell, R., Schreiber, B., Anderlind, K., Baes, K. (2014). Value engineering of capital projects. https://www.adlittle.com/sites/default/files/viewpoints/ ADL_Value_Engineering_01.pdf.

[33] Mostafaeipour, A. (2016). A novel innovative design improvement using value engineering technique: A case study. Journal of Optimization in Industrial Engineering, 9(19): 25-36. https://doi.org/10.22094/JOIE.2016.227

[34] Zainudin, W.N.R.A., Ishak, W.W.M., Sulaiman, N.A. (2017). Conceptual framework of Tenaga Nasional Berhad (TNB) Cost of Service (COS) model. Journal of Physics: $\quad$ Conference Series, 890(1). https://doi.org/10.1088/1742-6596/890/1/012100

[35] Berhad, T.N. (2017). Integrated Annual Report. Tenaga Nas. Berhad.

[36] Yin, R.K. (2009). Chapter 5 - Analyzing case study evidence. Case Study Res. Des. Methods, 127-164.

\section{NOMENCLATURE}

$\begin{array}{ll}\text { VE } & \text { Value Engineering } \\ \text { MEDS } & \text { Main Electric Distribution Station } \\ \text { VA } & \text { Value Analysis } \\ \text { IVE } & \text { Integrated Value Engineering } \\ \text { KPIs } & \text { Key Performance Indicators } \\ \text { FAST } & \text { Function Analysis System Technique } \\ \text { MESI } & \text { Malaysia Electricity Supply Industry } \\ \text { EUC } & \text { Energy Utility Company } \\ \text { MDS } & \text { Main Distribution Sub-station } \\ \text { MSS } & \text { Main Switching Station } \\ \text { LVAC } & \text { Low Voltage Alternate Current } \\ \text { RMU } & \text { Ring Main Unit } \\ \text { F.R.P } & \text { Fibre-Reinforced Plastic } \\ \text { RM } & \text { Malaysian Ringgit }\end{array}$

